\title{
Physical Infrastructure Planning and Management for Sustainable Development in Ramtek Town
}

\author{
Kalpana N. Kawathekar (Thakare) ${ }^{1}$, A. J. Sanyal ${ }^{2}$ \\ ${ }^{1}$ Research Scholar, RashtrasantTukadojiMaharaj Nagpur University, Nagpur and Associate Professor, Dept. of Arch, K.I.T.S., Ramtek, \\ Nagpur, Maharashtra, India
}

${ }^{2}$ Supervisor, Former Principal and Presently Professor, Design Chair, M.I.E.T.

\begin{abstract}
Infrastructure is the basic physical and organizational structures needed for the operation of a society necessary for an economy to function and physical networks that support society.Socio-economic growth of a town is motivated by means of socioeconomic and more so with the physical Infrastructure development in the town. It prerequisites the input in the form of working on land resource and physical infrastructure viz. roads, rail, water supply, drainage and solid waste management. Urban Local Agencies then become responsible for fulfilling the physical infrastructure requirements thus developing the area with every development stage. Many times Urban Local Bodiesoverlook the sustainability aspect while working on physical growth of a town as they do not contemplates of the quantity and the quality of the resources available. This bring in the issues of unsustainability of physical infrastructure affecting the overall sustainable development in town. Hence,Architect planners should consider the carrying capacity of the resources available in the vicinity of the town while planning the development so that local agencies can work for sustainable development.
\end{abstract}

Keywords: Physical growth, Infrastructure Development, Resources Management, IDSMT, PURA, Sustainability

\section{Introduction}

Sustainable development is a pattern of resource use that aims to meet human needs while preserving the environment so that these needs can be met not only in the present, but also for future generations. Planning is an attempt to formulate the principles that should guide us in creating a realized physical background for human life, Thomas Sharp. Infrastructure is the physical framework of services, facilities and amenities in the development planning. It can be divided into following types: i) Physical, ii) Social, iii) Economic, iv)Electronics, v) Ecological, vi) Defense, vii) Hazard/ emergency. It is one of the most important driving forces for economic development. A strong correlation between growth and infrastructure stocks is usually expected (World Bank, 1994; Canning, 1998; Fay and Yepes, 2003). Infrastructure Planning and Management can be termed as the optimization of the use of different resources in order to achieve the thoughtful planning in a way to have sustainable development.

Handling sustainability of Infrastructure in large urban areas is very complex issue as it has manifold activities and number of systems integrating for forming an urban agglomeration. Instead, the small and medium towns are as such having the population with in control limit. These towns usually have few growth poles around which the development of the town usually happens to continue.

During $6^{\text {th }}$ Five Year plan of planning commission, Government of India has stated the aim for IDSMT i.e. Integrated Development of Small and Medium Towns. It had mentioned the need to divert the population from large urban agglomerations thereby allowing the facilities provision at small and medium towns. Former President of India, Late Dr. A. P. J. Abdul Kalam has also specified the need of PURA i.e. Planning of Urban amenities in Rural
Areas. Dr. A. P. J. Abdul Kalam had stated that facilitating required infrastructure in rural base areas will allow the growth of these regions thereby reducing out migration and further maintaining the infrastructure in large urban areas due to reduced or no in migration.

Considering the above,research was worked on physical infrastructure planning and management for sustainable development of the small town in the rural region having a large urban agglomeration very nearby to attract the migrants. Area selected for the research formulation is Ramtek. Ramtek is ,ce category town having historic and pilgrimage importance with the population around 22,310 (Census of India 2011) on Northeast of Nagpur city from Vidarbha region of Maharashtra, India. The geographical location of Ramtek shows coordinates of Ramtek as $21^{\circ} 24$ " North Latitude and $79^{\circ} 20^{\prime \prime}$ East Longitude with the altitude of 315.3 metres above Mean Sea Level.

Historic Development of Ramtek shows organic growth with the settlements from different religious and cultural background. It is an important site in the Vidarbha Region. The area is rich in natural resources with the presence of water bodies, forest, flora and fauna, black cotton soil etc. The occupation of the people in the historic period was mainly agriculture and allied activities with the use of appropriate materials for the household activities and for construction of buildings. Today Ramtek has undergone development in various stages as a religious centre, administrative centre, educational centre, industrial centre and commercial centre. To start with it observed the spread from hill i.e.,gad' to foothills. Increase in the population has given Physical growth of Ramtek in different phases. 


\section{International Journal of Science and Research (IJSR) \\ ISSN (Online): 2319-7064}

Index Copernicus Value (2013): 6.14 | Impact Factor (2015): 6.391

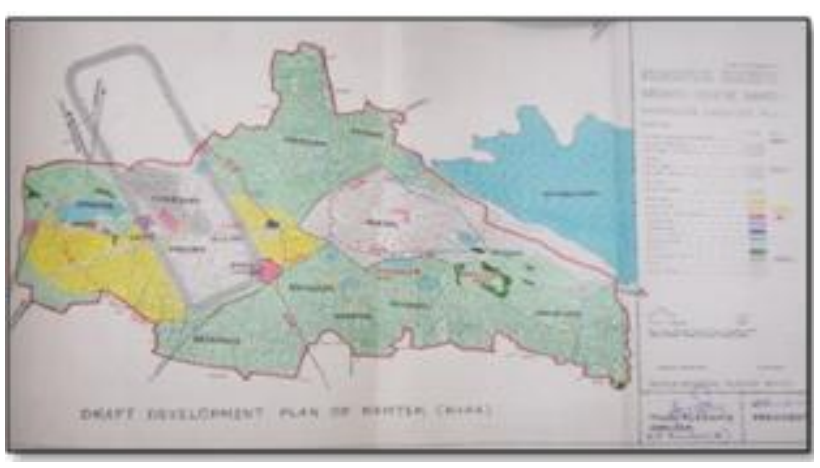

Figure 1: Development Plan 2013 of Ramtek marking its Spread

The town has seen two Development Plans till date, Development Plan 1971-91 and Development Plan 19932013. The Development Plan 2013 is continued further. The Development Plan 1(1991) had defined the boundary for the Urban Local Body. Development plan 2 (2013) has stated the fringe development for socioeconomic growth as it has already been using the urban infrastructure.

Looking in a spectrum the Ramtektown observes the organic growth.

Physical growth in Ramtek can be observed in phases as follows.

Phase I: Early settlement on north of the hill at Jain Temple. Phase II: Settlements at the western side foothills and near the water bodies (Lakes). Phase III: Extension of settlements along the south side of the foothill. Phase $I V$ : British period settlements and government offices on the far west of the foothillsand near Railway Station. Phase $V$ : Bazar area, Extension of road from Bazar to Jain Mandir across Gandhi Square. Phase VI: Area near New Bus Stand thus extending from Gandhi Square to Bus Stand. Phase VII: Contemporary/ Modern Developments beyond Bus Stand i.e. beyond the boundary of original development plan. .

The growth pattern shows that the growth was made from foothills to uphill area and on the outside. With time the pattern of growth has changed due to growth centres.

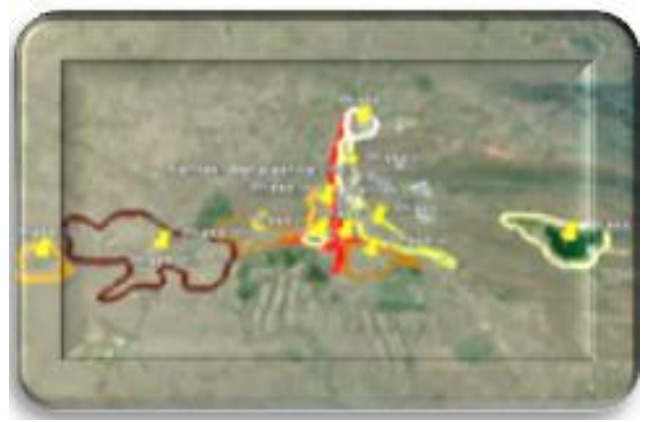

Figure 2: Phase wise growth pattern of Ramtek shown on Google image

\subsection{Objectives}

With the aim to formulate planning and management strategies for sustainability of physical infrastructure considering sustainable development of a town Ramtek the objectives are framed as below:

- To study the guidelines and regulations for infrastructure development and its sustainability for small and medium towns.

- To review and analyze the research and practices on sustainable infrastructure development.

- To identify the challenges related to physical infrastructure development \& its sustainability in general and particularly in case town.

- To determine the parameters to develop the strategies for sustainable development of physical Infrastructure in small and medium towns.

\subsection{Research questions}

1) Is development happening in Ramtektown?

2) Whether Development of case townRamtek is conducive to Sustainable Development?

3) Does Development of a town complement to Sustainability of Physical Infrastructure?

4) How the infrastructure can continue to be Sustainable?

\subsection{Methodology}

An empirical and field investigation method has been adapted to carry out analytical study for the case. The Questionnaire was formed and answered by different group of users including regular users of the physical

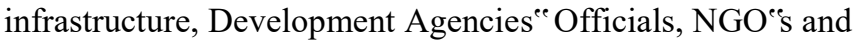
non-officials. Using statistical analysis for the data based on opinions of the users the analysis is computed.

\section{Literature Review}

On the population growth and worlde's development at the international level United Nations give the need for a holistic approach to urban development and human settlements that provides for affordable housing and infrastructure. It observes the need to prioritize slum upgrading and urban regeneration.

The MDGe's for sustainability of the world 's nations asks for the sustainability of Infrastructure through goal numbers 6 , 7, 9 and 11 which are devoted to ensure availability and sustainable management of water and sanitation for all, Ensure access to affordable, reliable, sustainable and modern energy for all, Make cities and human settlements inclusive, safe, resilient and sustainable. The World Bankreviews the growth towards sustainability on regular basis. The various issues are being discussed continuously through summits held at different places in the world to ensure the sustainable development throughout the nations.

TERI, under Ministry of New and Renewable Energy, Govt. of India, N. Delhi has given the guidelines for sustainability under heading GRIHA for Large Developments which can be considered for checking the sustainability of town. The sustainability through site planning, Energy, Water and waste water, solid Waste Management, Transport will help checking the social sustainable Development. 


\section{International Journal of Science and Research (IJSR) \\ ISSN (Online): 2319-7064 \\ Index Copernicus Value (2013): 6.14 | Impact Factor (2015): 6.391}

Literature reviewed to understand the trend in Physical Infrastructure Planning, Management for sustainability of town give observations as below:

- The development of town should be in line with the geography and the natural resources availability. Development of town should go with the resources cycle.

- There needs to have management and administration along with the planning for sustainable development of Physical and other Infrastructures in town,

- Conservatory design and layouts of Physical Infrastructures: Road, Water supply, Drainage, Sewerage and Solid Waste Disposal should be adopted.

- Support system/s for Physical Infrastructure Planning and Management should be developed by the town in the town.

- Large Urban center or an urban agglomeration should be within reach from the town sustainability of growth of town.

\section{Physical Infrastructure Study}

\subsection{Water Supply}

Ramtek Town is provided with tax water supply. The source of water is from Ram sagar (Khindsilake) $6 \mathrm{~km}$. away from Municipal limit. The water is taken to two reservoirs one at Ambala of 2,25,000litres capacity and other to the south of Ram Giri Hill and at the foot of Dumreshwar temple with 22,500 litrescapcity. Filtration plant is provided for purification of water. This scheme is designed for population of 30,000 souls providing water supply consumption of litres per capita per day for the town and 22.5 litres per capita per day pilgrims. The water survey scheme is under control and management of Maharashtra Water Supply and Sewerage Board. However, it is to be handed over to local planning authority i.e. Municipal Council as per decision of State Government.

Water supply scheme is sustainable for Ramtek as it is designed for the population projection up to 30,000 souls. The source of water would be available in quantity sufficient for next 2 decades as per the today's growth rate. The water supply line network extension to cover the newly developed areas is under progress.

\subsection{Drainage and Sewerage}

There is no underground drainage scheme in the town for systematic arrangements of drainage and sewerage disposal. The Municipal Council has constructed open drains by the sides of roads. However, along with some 7 main roads pucca covered drains are provided. The Houses in the town have latrines with septic tank. Municipal Council has constructed public latrines at different locations suitable to poor section of the society. Drains of Ramtek are naturally flown into the water tanks and others are flown to rivers Sur and Kapila through artificial drain nalas on the South West of Ramtek.

The individual house in Ramtek observes septic tanks for the Sewage collection and the evacuation of the tanks is carried by the Municipal Council representatives. There are public latrines are provided at certain public locations but need more numbers along with the maintenances.

\subsection{Solid Waste Management}

The urban solid Waste is collected through waste bins located at different places in the town. By means of tractor trolley it is being carried and dumped in the Municipal land earmarked for compost depot on Bye pass road near shantinath. Solid Waste Management is thought by the urban local body. The collection of solid waste is started towards sustainability. The recycling of waste generated is being worked towards power generation.

\subsection{Power Supply}

Maharashtra State Electricity Board supplies electricity to Ramtek town. The substation of the Maharashtra State Electricity Board is situated outside Municipal limit on Mansar road, $7 \mathrm{kms}$. Away from the town. The source of electricity is obtained from koradi Thermal Power Station.

\subsection{Road}

Mansar - Tumsar along E-W road and Shantinath Temple road along N-S, are important routes of the town. The most of commercial activities are concentrated on these two roads. Similarly, other existing roads are narrow, zig-zag with topographically up and down. The byepass road provides decongestion of traffic shantinath Temple Road from western side joining Mansar-Tumsar Road on one end while Muswadi Road (Shantinath Temple Road) on other end, is under completion as per the Development Plan proposal as per the alignment proposed in the Draft regional plan of Nagpur. In all $47.48 \%$ of villages in the Ramtek region are having connectivity to Ramtek by pucca road and $57.83 \%$ of villages are having bus stop. Distance of villages vary between $1-15 \mathrm{kms}$. All of these villagers use the physical infrastructure in Ramtek town on regular basis.

Road width for main roads and internal roads is observed as inadequate. There are plan proposals in the regional plan for widening of the main roads.

\section{Analysis}

For the analysis Random sampling method is used. For data collection assessment and interpretation of perceptions of respondents, the researcher has distributed questionnairesamong the 441 regular users and 98 Development representatives. The respondents include regular users of the physical infrastructure in Ramtek, Development Agencies ${ }^{e e}$ Officials, NGO's and non-officials. With these questions and their answers the significance of the hypothesis made before the research is tested. The statistical method has been used for the data calculations and analysis. The data analysis is done by computation. The analysis has proved helpful to assess the physical infrastructure sustainability in Town and its relevance.

The summary of responses of the regular users and the development representatives from the sample survey is given below in Table 1 and Table 2 . There is a tendency to 


\section{International Journal of Science and Research (IJSR) \\ ISSN (Online): 2319-7064 \\ Index Copernicus Value (2013): 6.14 | Impact Factor (2015): 6.391}

show high value for the positive values as the graphs show high values towards left of central tendency. In the tables below the neutral (middle) opinion is rejected to avoid central tendency. The average of first two responses viz., strongly agree and agree are compared to last two responses (disagree and strongly resist) and are taken in percentage scale to observe the perceptions of regular users and development representatives respectively.

Table 1: The average of first two and last two responses of Regular users for development of physical infrastructure and overall sustainability of town

\begin{tabular}{|c|c|c|c|c|c|c|c|c|}
\hline Particulars & $\begin{array}{c}\text { Strongly } \\
\text { agree }\end{array}$ & Agree & Total & $\%$ & Disagree & $\begin{array}{c}\text { Strongly } \\
\text { disagree }\end{array}$ & Total & $\%$ \\
\hline Road & 235 & 180 & 415 & 94.1 & 4 & 3 & 7 & 1.5 \\
\hline SW M & 206 & 166 & 372 & 84.35 & 14 & 4 & 18 & 4.08 \\
\hline Water S & 116 & 142 & 258 & 58.5 & 75 & 27 & 102 & 23.12 \\
\hline Drainage & 230 & 145 & 375 & 85.03 & 13 & 11 & 24 & 5.44 \\
\hline Sewage & 150 & 158 & 308 & 69.84 & 49 & 10 & 59 & 13.37 \\
\hline Average & 187.4 & 158.2 & 345.6 & 73.36 & 31 & 11 & 42 & 9.502 \\
\hline
\end{tabular}

Table 2: The average of first two and last two responses of development representatives for development of physical infrastructure and overall sustainability of town

\begin{tabular}{|c|c|c|c|c|c|c|c|c|}
\hline Particular & $\begin{array}{c}\text { Strongly } \\
\text { agree }\end{array}$ & Agree & Total & $\%$ & Disagree & Strongly resist & Total & $\%$ \\
\hline Road & 43 & 28 & 71 & 72.44 & 12 & 1 & 13 & 13.26 \\
\hline SWM & 42 & 26 & 68 & 69.38 & 11 & 03 & 14 & 14.28 \\
\hline Water S & 27 & 32 & 59 & 60.20 & 17 & 10 & 27 & 27.55 \\
\hline Drainage & 23 & 28 & 51 & 52.04 & 29 & 9 & 38 & 38.77 \\
\hline Sewage & 20 & 29 & 49 & 50.0 & 27 & 11 & 38 & 38.77 \\
\hline Average & 31 & 28.6 & 59.6 & 60.81 & 19.2 & 6.8 & 26.0 & 26.53 \\
\hline
\end{tabular}

The data is analyzed through advanced Statistical method. Chi-Square Test of Independent issues to analyze the frequencies of two qualitative variables is used for comparing frequencies (count) of nominal or ordinal level data for two samples across two or more subgroups.

From the sample survey data and the opinions of the representatives the observations are formulated and using the chi square method the calculations are done to test the hypothesis. The analytical calculations show that majority of the regular users and development representatives agree of the development of physical infrastructure and sustainability of town, whereas few of the users and development representatives do not agree of the same, thus intuitively, from the bar diagrams and the tables, the null hypothesis is rejected and the alternative hypothesis is tested using Pearsons ${ }^{\text {ee }}$ contingency coefficient for association.

Hypothesis $\mathrm{H}_{1}$ and $\mathrm{H}_{2}$ is tested and concluded by finding coefficient of association (Strength). It gives Physical Infrastructure development for Sustainability of town as positive but the degree of association as less than 5 i.e. showing low performance. Pearsones Contingency Coefficient $(\mathrm{C})$ for both regular users andfor Development representatives is low and moderate association respectively. This gives the analysis that Physical Infrastructure development for Sustainability of town is positive but not perfect.

\section{Conclusion and Suggestions}

\subsection{Conclusion}

The Ramtek town shows Development trend. The Development is positive towards sustainable growth of the town. The physical infrastructure is available for the need of the town. It observes development but not at par with the demand.

Water supply: Water is available in required quantity for the population. To maintain it the conservation measures must be adapted Separate pipelines for Water supply to urban and rural areas have been made.

Solid Waste management: The collection of the waste is well done by the trolley and it is disposed of in the outskirt of the town.

For Sewerage collection there is no layout provision made in this region hence every house has its own septic tank. The provision of layout for sewage may reduce the construction area for the separate Septic Tanks.

Roads are undergoing widening.

With the growth of settlements there is observed an encroachment on the natural settings.

Cleanliness of environment: To maintain the surrounding environment neat and clean the local agents are working out the ways as under:

- Encroachment Removal: To remove the encroachments if any along the streets which is creating obstruction for the public traffic. Under this the encroachments along the main cross road of Gandhi Square (main square near central Bazar) and the encroachments of the shop keepers and their residences on the ,Ramgad ${ }^{\text {ee }}$ which is a property of the private trust and the government are all removed during 2010-12.

- Tree Plantation: Under Environment protection mission the tree plantation was done by the local agencies. The targeted and completed are is $6 \mathrm{Sq}$. Kms. The total number of trees planted under this mission are 12,225 as 


\section{International Journal of Science and Research (IJSR) \\ ISSN (Online): 2319-7064}

Index Copernicus Value (2013): 6.14 | Impact Factor (2015): 6.391

targeted in 2010-11, and around 20,000 in this season (rainy) 2016 .

- Under protection of natural forest and Wild animals the work was undertaken in Pench Reserved forest.

\subsection{Suggestions}

Local Agencies have been working actively for the Management of the infrastructure with multi fold activities but the problems are continued further. The suggestions to overcome the problems may be as follows:

- Public Private Participation: Actively involving the people who are any ways related to the particular infrastructure

- Conservation Management of resources: Using the principles of sustainability of resources Reduce, Reuse and Recycle all the resources viz. land, water, forest and environment be used.

- Infrastructure Development: Development of Infrastructure as per the need of the population. Promote use of alternative resources for the infrastructure

\section{Summary}

Organic growth of the settlement results in inadequacy of infrastructure in the long run. This is faced by both inhabitant and development representatives affecting the sustainability of town. This inadequacy of the infrastructure can be judged and understood before actually facing it. IDSMT and PURA are the solutions to reduce the difficulty of managers as administrators who work for the whole life in solving the problems due to inadequate planning. IDSMT stands for ,Integrated Development of Small and Medium Towns ${ }^{\text {ee }}$ whereby the development is planned and promoted in an integrated manner for both small and medium towns in order to reduce the load on the infrastructure in urban agglomerations. PURA meaning „Planning of Urban amenities in the Rural Areas, also allows the development of the rural base areas with the distribution of infrastructure convenient with it. Ramtek though being a small town and a taluka centre is no more an exception for this but Sustainable Development can be achieved with the solicitous planning and stringent administration.

\section{References}

[1] "Census data online Maharashtra all districts". Censusindia.gov.in.

http://www.censusindia.gov.in/Census_Data_2001/Cens us_Data_Online/Population/Total_Population.aspx. Retrieve-d 2010

[2] Au-Yeung, Benson, Saad, Andrew, \&Yigitcanlar, Tan (2010), Sustainable urban infrastructure management: integration of urban computer modelling. In: Proceedings of the 3rd Knowledge Cities World Summit: From Theory to Practice, 16-19 August 2010, Melbourne, Victoria.) QUT Digital Repository: http://eprints.qut.edu.au/

[3] Draft URDPFI Guidelines 2014, Ministry of Urban Development, India.

[4] Energy Conservation Building Codes, Bureau of Energy Efficiency, N. Delhi, India July 2009.
[5] Final Report, A Study to Qualitatively Assess the Capacity Building Needs of Urban Local Bodies (ULBs), August, 2015, Research Division, NITI Aayog, Government of India

[6] Flint, R.W. and M.J.E. Danner. 2001, The nexus of sustainability and social equity. Int. J. Econ. Dev.

[7] GRIHA Manual for Large Developments, Association for Development and Research for Sustainable Habitat.

[8] http://niti.gov.in/mgov_file/presentations/Reviewing $\% 2$ 0Progress $\% 20 \mathrm{in} \% 20$ achieving $\% 20$ Infrastructure $\% 20 \mathrm{Ta}$ rgets $\% 20$ for $\% 202015$.pdf

[9] https://data.gov.in/catalog/villagetown-wise-primarycensus-abstract-2011-maharashtra

[10]Int. J. , Vol. x, No. x, xxxx1, Copyright (C) 200x Inderscience Enterprises Ltd., Research agenda for an integrated approach to infrastructure planning, design, and management, R. John Hansman, Christopher Magee, Richard de Neufville, Renee Robins and Daniel Roos, Massachusetts Institute of Technology, Cambridge, USA

[11] Linda Groat and David Wang, Architectural Research Methods, New York: John Wiley and Sons, 2002, Reviewed by Kerry London and Michael Ostwald, Edition $2^{\text {nd }}$

[12] Methodology and Techniques of Social Research by Wilkinson and Bhandarkar.

[13] Nagpur District Statistical Report 2011, Government of Maharashtra

[14]National Conferences of ITPI: Conclusions and Recommendations, Septebmer 2015, Edited by Prof. Dr. D. S. Meshram .

[15] Paper by S Puranik, A. Deshpande, and Y. Pawshe on 'Unraveling Secrets: Ramtek model', from 'Making water everybody's business, practice and policy of water harvesting' edited by Anil Agarwal, SunitaNarain and Indira Khurana Centre for Science and Environment Report,2000, pg.no. 154.

[16] Physical Planning Thought : Retrospect and Prospect, Gary Pivo, Cliff Allis, Michael Leaf, Gerald Megatu , The Journal of Architectural and Planning Research, Chicago, Spring 1990.

[17] Post Graduation Thesis Report by Kalpana N. Kawathekar, MURP II , IIT Roorkee, 2006 on "Planning for Integrated development of RamtekTaluka".

[18] Post Graduation Thesis Report by Rajendra A. Dongre, SPA, N. Delhi, 1991on „Citizens Perception and Urban Planning, Case study: Ramtek, Nagpur District ${ }^{\mathrm{C}}$.

[19]PPT Presentation By NITI Aayog , Infrastructure: Powering Growth through Connectivity, May 2015

[20] Rama Yagya Singh \&Alok Kumar Singh, ,Planning in Integrated rural environment ${ }^{\text {ee }}$

[21] Ramtek Development Plan 2013

[22]Report of the Committee on Indi Vision 2020, Chairman Dr. S. P. Gupta, Planning Commission, Government of India, New Delhi, DECEMBER, 2002

[23] Report of the United Nations Conference on Sustainable Development, Rio de Janeiro, Brazil, 20-22 June 2012.

[24] Research agenda for an integrated approach to infrastructure planning, design, and management, $R$. John Hansman, Christopher Magee,Richard de Neufville, Renee Robins and Daniel Roos, 
Massachusetts Institute of Technology, Cambridge, USA, E-Mail: ardent @ mit.edu

[25] Research Methodology, Methods and Technology by C. R. Kothari, New Age Publications

[26] Sampling theory of Surveys with application by Sukhatme.

[27] Sharma J. K., 2007, "Business Statistics", Pearson, P: $381-401$

[28] Transformation through Infrastructure, The working group Report, World Bank for 2012-15.

[29] UjjwalaKhot, Post Graduation Thesis Report on "Conservation Guidelines for the development of Ramtek cultural region", SPA, Delhi, 2005.

[30]UN The General Assembly Report 2015, on Transforming our world: the 2030 Agenda for Sustainable Development, Adopts the following outcome document of the United Nations summit for the adoption of the post-2015 development agenda:

[31] Working paper on A Simple Model to Evaluate Relative Urban Conditions, Vittorio E. Pareto IV.

[32] Working paper on Effects of Improving Infrastructure Quality on Business Costs:Evidence from Firm-Level Data, Atsushi Iimi, The World Bank Finance, Economics and Urban Development Department, Economics Unit, March 2008.

[33] World Bank Group, Sustainable Infrastructure Action Plan, Fiscal Years 2009-2011.

[34] www.censusindia.gov.in/ census2011

\section{Author Profile}

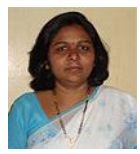

Ms. Kalpana N. Kawathekar (Thakare) is an Architect from M.I.E.T., Gondiaand Planner from IIT Roorkee and is pursuing Research in Architecture and Planning under faculty of Engg. \& Technology at R.T.M.N.U, Nagpur. Formerly she was The Head, and now Associate Professor at Dept. of Arch, K.I.T.S., Ramtek.

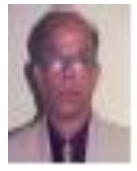

Professor A. J. Sanyal, is an Architect and Planner from Nagpur Region. He is a former Principal and presently Professor, Design Chair at M.I.E.T., Gondia.Sir is an academician and professional with expertise in spectrum of subjects. 